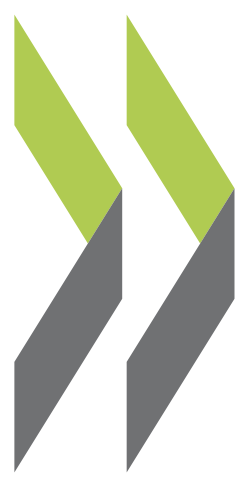

OECD Economics Department Working Papers No. 1336

$$
\begin{aligned}
& \text { The Use of Models } \\
& \text { in Producing OECD }
\end{aligned}
$$

\title{
David Turner
}

Macroeconomic Forecasts 
Organisation de Coopération et de Développement Économiques

Organisation for Economic Co-operation and Development

26-Oct-2016

ECONOMICS DEPARTMENT

English - Or. English

THE USE OF MODELS IN PRODUCING OECD MACROECONOMIC FORECASTS

ECONOMICS DEPARTMENT WORKING PAPERS NO. 1336

By David Turner

OECD Working Papers should not be reported as representing the official views of the OECD or of its member countries. The opinions expressed and arguments employed are those of the author(s).

Authorised for publication by Christian Kastrop, Director, Policy Studies Branch, Economics Department.

All Economics Department Working Papers are available at www.oecd.org/eco/workingpapers

JT03403731

Complete document available on OLIS in its original format

This document and any map included herein are without prejudice to the status of or sovereignty over any territory, to the delimitation of international frontiers and boundaries and to the name of any territory, city or area. 
OECD Working Papers should not be reported as representing the official views of the OECD or of its member countries. The opinions expressed and arguments employed are those of the author(s).

Working Papers describe preliminary results or research in progress by the author(s) and are published to stimulate discussion on a broad range of issues on which the OECD works. Comments on Working Papers are welcomed, and may be sent to the Economics Department, OECD, 2 rue André-Pascal, 75775 Paris Cedex 16, France.

Comment on the Papers is invited, and may be sent to OECD Economics Department, 2 rue André Pascal, 75775 Paris Cedex 16, France, or by e-mail to eco.contact@oecd.org.

This document and any map included herein are without prejudice to the status of or sovereignty over any territory, to the delimitation of international frontiers and boundaries and to the name of any territory, city or area.

The statistical data for Israel are supplied by and under the responsibility of the relevant Israeli authorities. The use of such data by the OECD is without prejudice to the status of the Golan Heights, East Jerusalem and Israeli settlements in the West Bank under the terms of international law.

Latvia was not an OECD Member at the time of preparation of this publication. Accordingly, Latvia does not appear in the list of OECD Members and is not included in the zone aggregates.

\section{(C) OECD (2016)}

You can copy, download or print OECD content for your own use, and you can include excerpts from OECD publications, databases and multimedia products in your own documents, presentations, blogs, websites and teaching materials, provided that suitable acknowledgment of OECD as source and copyright owner is given. All requests for commercial use and translation rights should be submitted to rights@oecd.org 
ECO/WKP(2016)60

\section{ABSTRACT/RÉSUMÉ \\ The use of models in producing OECD macroeconomic forecasts}

This paper firstly describes the role of models in producing OECD global macroeconomic forecasts; secondly, reviews the OECD's forecasting track record; and finally, considers the relationship between forecast performance and models. OECD forecasts are not directly generated from a single global model, but instead rely heavily on expert judgment which is informed by inputs from a range of different models, with forecasts subjected to repeated peer review. For the major OECD economies, current year GDP growth forecasts exhibit a number of desirable properties including that they are unbiased, outperform naïve forecasts and mostly identify turning points. Moreover, there is a trend improvement in current-year forecasting performance which is partly attributed to the increasing use of high frequency 'now-casting' indicator models to forecast the current and next quarter's GDP. Conversely, the track record of one-year-ahead forecasts is much less impressive; such forecasts are biased, often little better than naïve forecasts and are poor at anticipating downturns. Forecasts tend to cluster around those from other international organisations and consensus forecasts; it is particularly striking that differences in one-year-ahead forecasts between forecasters are relatively minor in comparison with the size of average errors made by all of them. This may reflect herding behaviour by forecasters as well as the mean reversion properties of models. These weaknesses in forecasting performance beyond the current year underline the importance of increased efforts to use models to characterise the risk distribution around the baseline forecast, including through the increased use of model-based scenario analysis.

JEL Classification: E17, E27, E32

Keywords: Forecasting, economic outlook, GDP growth, models.

\section{Le rôle des modèles dans la production des prévisions macroéconomique de l’OCDE}

Ce document décrit le rôle des modèles dans la production des prévisions macroéconomiques mondiales de l'OCDE, analyse a posteriori la performance des prévisions passées et examine le lien entre la qualité des prévisions et les modèles utilisés. Les prévisions de l'OCDE ne sont pas élaborées directement à partir d'un modèle mondial unique, mais reposent en grande partie sur des avis d'experts eux-mêmes formés à partir d'éléments provenant de différents modèles. Ces prévisions sont soumises à des spécialistes dans le cadre d'un processus itératif. En ce qui concerne les grandes économies de l'OCDE, les prévisions de croissance du PIB pour l'année en cours présentent un certain nombre de caractéristiques appréciables : elles sont non biaisées, plus exactes que les prévisions «naïves» et, dans la plupart des cas, identifient les points de retournement. En outre, on observe une amélioration tendancielle de la performance des prévisions pour l'année en cours, qui est en partie imputable au recours récent à des modèles d'indicateurs à haute fréquence permettant de prévoir le PIB du trimestre en cours et à venir (now-casting), mais aussi au poids croissant accordé à ces modèles et à l'amélioration de la qualité de leurs résultats. A contrario, l'analyse des prévisions à un an est bien moins convaincante; ces prévisions sont biaisées, à peine meilleures que les prévisions «naïves » et peu efficaces pour prévoir les retournements de conjoncture. Elles sont généralement proches de celles des autres organisations internationales et du consensus des prévisionnistes, mais il est particulièrement frappant de constater que les disparités existant entre les prévisions à un an des différents prévisionnistes sont moindres comparées à l'ampleur des erreurs moyennes commises par l'ensemble de ces acteurs. Ce constat peut s'expliquer par le comportement moutonnier des prévisionnistes mais également par la tendance au retour à la moyenne qui caractérise les modèles. Ces faiblesses dans les prévisions à plus d'un an montrent qu'il importe d'intensifier les efforts visant à utiliser des modèles pour définir la distribution des risques autour de la prévision de référence, notamment en recourant davantage à l'analyse s'appuyant sur des modèles permettant de construire des scenarios.

Classification JEL: E17, E27, E32

Mots clés: Prévisions, perspective économique, croissance du PIB 


\section{TABLE OF CONTENTS}

\begin{tabular}{|c|c|}
\hline \multirow{2}{*}{\multicolumn{2}{|c|}{$\begin{array}{l}\text { 1. Introduction .......................... } \\
\text { 2. The forecasting round }\end{array}$}} \\
\hline & he forecasting round \\
\hline \multicolumn{2}{|c|}{ 3. The role of models.. } \\
\hline 3.1 & Global macroeconomic models .. \\
\hline 3.2 & Financial Conditions Indices ......................... \\
\hline 3.3 & Now-casting models \\
\hline 3.4 & The Forecast Entry system \\
\hline 3.5 & The trade model and global consistency \\
\hline 3.6 & 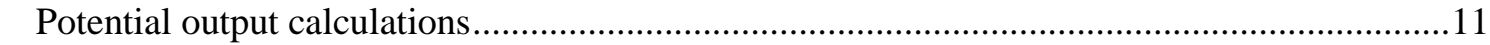 \\
\hline & he forecasting track record... \\
\hline 4.1 & Forecast performance for the current year is much better than for the following year .............12 \\
\hline 4.2 & Current-year forecast performance has improved over time \\
\hline 4.3 & Forecasts are strikingly similar to the consensus and other international organisations ...........14 \\
\hline 4.4 & Forecasts are still particularly vulnerable around major global shocks \\
\hline 0 & 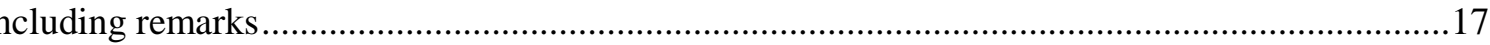 \\
\hline
\end{tabular}

\section{Tables}

Table 1. Global macro models used in the forecasting process at the OECD ….....................................

Table 2. RMSE OECD Economic Outlook GDP growth projections over the longer run ........................13

\section{Figures}

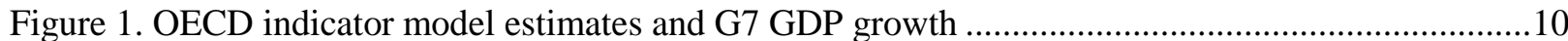

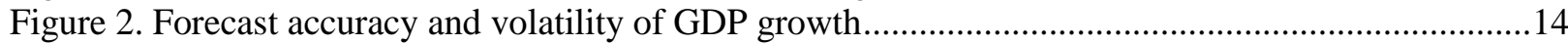

Figure 3. One-year-ahead forecast errors for GDP growth...............................................................16 
ECO/WKP(2016)60

\title{
THE USE OF MODELS IN PRODUCING OECD MACROECONOMIC FORECASTS
}

\author{
David Turner ${ }^{1}$
}

\section{Introduction}

1. This paper firstly describes the role of models in producing OECD global macroeconomic forecasts; secondly, reviews the OECD's forecasting track record; and finally, considers the relationship between forecast performance and models. It is worth emphasising at the outset that OECD forecasts are not directly generated from a single global model. While a global model does play a role, OECD forecasts are instead produced using a combination of different models combined with expert judgement and peer review by both insiders and outsiders. This process is a means to reconcile a 'bottom-up' approach, in which country forecasts are based largely on the judgement of experts with detailed knowledge of that country, and a more model-based 'top-down' approach, which ensures that forecasts are based on common assumptions and that linkages between countries are properly accounted for.

2. The rest of the paper is organised as follows: the next section provides an overview of the forecasting round at the OECD, since an appreciation of this context is essential for understanding the role of models in the process; in Section 3 the various modelling tools which are used in generating OECD forecasts are discussed; in Section 4 the OECD's forecasting track record is reviewed; Section 5 provides some concluding remarks, including speculation on how the use of models may have influenced forecast performance as well as highlighting recent changes in the forecast process.

\section{The forecasting round}

3. The forecasts published twice a year in the OECD Economic Outlook are the outcome of a forecasting round which lasts seven to eight weeks. The length of this process is necessitated by the series of reviews to which the forecasts are subjected and so is a reflection of the relative weight which is attached to judgement, rather than relying on the mechanical outcome from a single model. In between the publication of OECD Economic Outlooks, an interim update of the forecasts is published. However, the procedures underlying this interim update, including the use of models, are less intensive, with the main focus on GDP and developments in the largest economies. Nevertheless, these interim updates are important, not least because they provide a more up-to-date 'baseline' for the following Economic Outlook Forecast Round.

1. This paper is based on a presentation given at a conference on 'Global Economic Modelling' in honour of Laurence Klein in Toronto in June 2015, with comments from the conference participants, especially Ken Wallis (Emeritus Professor of Econometrics, Warwick University), gratefully acknowledged.. The author has worked in the Economics Department at the OECD since 1991, since which time he has been involved in OECD forecasts in a variety of capacities; since 2009 he has been Head of the Macroeconomic Analysis Division, which is the division responsible for most of the models which are described in this chapter. The work of numerous colleagues at the OECD, on which this chapter heavily draws are gratefully acknowledged, as well as thoughtful comments on an earlier draft from Nigel Pain, Cyrille Schwellnus, Simon Kirby, Catherine Mann (OECD Economics Department), Roberto Astolfi and Pierre-Alain Pionnier (OECD Statistics Directorate). Thanks are also due both to the Independent Evaluation Office of the IMF and to the National Institute for Economic and Social Research for sharing data on forecast errors. My particular thanks to Jeroen Meyer and Gil Parola for additional statistical analysis and help in document preparation from Veronica Humi. 
4. The Economic Outlook forecast round starts with a scene-setting meeting known as the General Internal Meeting (or 'GIM') of all economists involved in the forecasts. ${ }^{2}$ The purpose of this meeting is to provide guidance on how the forecasts should be revised relative to the previous published forecasts. This will involve taking stock of new information which has become available since the last forecast, particularly new data and the implications of the most recent high frequency monthly data. It will also involve an evaluation of the main changes in the 'forces acting', for example due to changes in commodity prices, exchange rates, monetary policy, other financial variables and fiscal policy.

5. The central guidance from the GIM has become more specific, formalised and been given greater weight in recent years reflecting a perception that cross-country spillovers from shocks have become increasingly important and may have contributed to similar forecasting errors across many OECD countries. ${ }^{3,4}$ Following the GIM, economists with specialised knowledge of particular countries, known internally as 'Country Desks', are responsible for submitting a preliminary forecast for individual countries. Country Desks have experience of monitoring specific OECD or non-OECD economies in order to produce a regular Economic Survey of that country and the expertise and contacts which they gain through this monitoring process means they are well placed to provide a macroeconomic forecast for 'their' country.

6. Once a preliminary set of forecasts have been generated for each country, the responsible Country Desks present their forecasts and are cross-examined on various aspects of them at the 'Internal Departmental Meeting' (or 'IDM'). On the basis of this internal scrutiny, the country forecasts are revised before being subject to external scrutiny at the meeting for 'Short Term Economic Prospects' (or 'STEP'), where (the still preliminary) OECD forecasts are systematically compared with national forecasts at a meeting attended by external country delegates with experience of forecasting, most often from Finance Ministries. Following discussion at the STEP meeting, and also to reflect new information which has since become available, the forecasts are revised a final time before being published in the OECD Economic Outlook. The forecast provides a focus for a narrative on the world economy and so a basis for policy assessment and advice which are also elaborated in the Economic Outlook.

\section{The role of models}

7. The most important modelling tools which contribute to OECD forecasts include: a global macroeconomic model; now-casting models; a trade model; models to determine potential output; and a 'Forecast Entry' model by which Country Desks enter their forecasts into a central database. The emphasis here is less on the detailed specifications underlying these models than on how they contribute to the forecasting process, although readers interested in the former should find further details in the appended references.

\subsection{Global macroeconomic models}

8. While global macroeconomic models do not directly generate OECD forecasts they do contribute to the process. For this purpose, a succession of global models has, until recently, been constructed and

2. Each meeting of the forecasting round is commonly referred to by an obscure acronym (GIM, IDM, STEP) which confuses newcomers, but to which insiders become quickly accustomed.

3. In a review of forecasting errors over the crisis period, Pain et al. (2014) found that growth was typically weaker and errors higher in countries that were more open to external developments and exposed to shocks from other economies.

4. The degree of centralisation in terms of top-down guidance that OECD Directors issue to Country Desks, is arguably now greater than in the forecast procedures of most other international organisations (Independent Evaluation Office of the IMF, 2014). 
maintained 'in-house' since the 1980s (Table 1). However, given the resource cost of updating and maintaining a global model, the OECD decided from around 2010 to make use of the NiGEM global model which is provided by the National Institute for Economic and Social Research (NIESR) in the United Kingdom.

Table 1. Global macro models used in the forecasting process at the OECD

\begin{tabular}{lcccccc}
\hline & Date from & $\begin{array}{c}\text { Number of } \\
\text { countries/ } \\
\text { regions }\end{array}$ & $\begin{array}{c}\text { Number of } \\
\text { variables in large } \\
\text { country sub-model }\end{array}$ & Frequency & $\begin{array}{c}\text { Wealth } \\
\text { variables? }\end{array}$ & $\begin{array}{c}\text { Forward- } \\
\text { looking? }\end{array}$ \\
\cline { 2 - 7 } INTERLINK $^{1}$ & Early 1980s & 30 & 250 & Semi-annual & No & No \\
Small Global Model $^{2}$ & 2001 & 4 & $<20$ & Quarterly & No & Yes \\
OECD Global Model $^{3}$ & 2006 & 9 & 300 & Quarterly & Yes & No \\
NiGEM $^{4}$ & 2010 & 50 & 500 & Quarterly & Yes & Yes \\
\hline
\end{tabular}

Note:

1. See Richardson (1988) and Daalsgard et al. (2001).

2. See Rae and Turner (2001).

3 See Hervé et al. (2010).

4. See NIESR (2016).

9. The INTERLINK model (Richardson, 1988) -- a large global model on a semi-annual frequency with distinct models for each OECD country and regional models covering the non-OECD -- was used throughout much of the 1980s and 1990s. A number of trends in the subsequent global models used by the OECD can be identified: reflecting a similar change in the published forecasts, there has been a move to a quarterly frequency; increased importance has been attached to the possibility of being able to run the model with forward-looking model-consistent expectations particularly to model the transmission of shocks through financial markets; and increased importance has been attached to modelling wealth in the transmission of shocks. The trend in the size of successive model is less obvious (Table 1): following INTERLINK there was a short-lived flirtation with a small global model with few regions and few variables in each region (Rae and Turner, 2001); a new OECD global model (Hervé et al., 2010) then focussed on modelling only the largest countries and regions, although with a large number of variables particularly to capture wealth effects; finally, NiGEM (NIESR, 2016) is the largest of the global models which has been used by the OECD, both in terms of the number of countries and variables covered in a typical country.

10. NiGEM separately distinguishes most OECD countries and the largest non-OECD countries, with other countries modelled in terms of regional blocks. It is based around a 'New-Keynesian' framework, with the long-run properties of equations imposed consistent with theory, but with dynamic adjustment estimated using historical data, so striking a balance between theory and data. Financial markets are presumed to be forward-looking, but with liquidity constraints, myopic behaviour and nominal rigidities in other sectors slowing the process of adjustment to shocks, although the model is also designed to be flexible so that assumptions regarding behaviour and policy can be readily changed.

11. The 'rental' and use in the forecasting round of a model from outside the OECD has the advantage of avoiding the heavy development and maintenance costs associated with a large scale global model. It also has the advantage that it comes with an established reputation given a wide user base which in the case of NiGEM includes many users from central banks, and finance ministries - and comes with a body of published papers describing the use of the model in policy exercises. The disadvantages of using an 'outside model' is that when model properties are queried (as, is inevitable with any large-scale macro model) those responsible for running the model are less willing and able to defend it, as it is "not their baby". Moreover, modifying the model in response to such criticism is difficult, whereas if the model 
was maintained "in-house" then critical feedback could more easily be channelled into amending and improving the model.

\subsubsection{The role of the global model in assessing changes in 'forces acting' since the previous forecast}

12. The global model plays a role in "setting the scene" at the start of each forecast round, by evaluating the macroeconomic effect of changes since the last published projections in commodity prices exchange rates, interest rates, fiscal policy, the path of economic activity and other key conditioning variables. The effects of the new elements and revised judgments are typically assessed on the basis of model simulations using the global model and their effects on GDP and inflation are evaluated. These results are, however, mechanical and therefore only one input to the central guidance to Country Desks following the GIM.

\subsubsection{The role of the global model in constructing alternative scenarios}

13. Probably the most important use of the global model is to consider variant scenarios around the central forecast, based on alternative assumptions about policy or key conditioning variables such as commodity prices. The scenarios are often published alongside a commentary on the central forecast in the General Assessment overview chapter of the Economic Outlook and have been given greater emphasis since the financial crisis, as a means of illustrating uncertainty and risks surrounding the central forecast. Past scenarios have covered a range of issues, which have recently included:

- A stylised downside scenario in the euro area [Box 1.6, OECD (2012)];

- Quantifying the macroeconomic effects of a binding US debt ceiling [Box 1.4, OECD (2013)];

- Risks in China's financial system and potential spillovers [Box 1.1, OECD (2014a)];

- Potential energy market spillovers from events in Ukraine [Box 1.2, OECD (2014b)];

- The global impact of weaker demand growth in China [Box 1.2, OECD (2015b)];

- The impact of an increase in public investment in OECD economies [Box 1.6, OECD (2015)];

- $\quad$ Financial market shocks from Brexit [Box 1.1, OECD (2016)].

\subsection{Financial Conditions Indices}

14. With the onset of the financial crisis, greater effort has been made to quantify forces acting through financial markets with the development of financial conditions indices for the major OECD countries (Guichard et al., 2009). These capture the effect of broadly defined financial conditions on economic activity and include not only standard text-book measures of policy interest rates and exchange rates, but also survey measures of bank lending conditions and interest rate spreads (the difference between government interest rates and the rates at which companies can borrow). The latter, less conventional, components are typically less well captured, if at all, in large macroeconomic models, but have been important in tracking the adverse effects of the financial crisis. Changes in these FCIs provide information, in addition to that provided by global model simulations, on the 'forces acting' since the last published forecast and so provide further guidance as to how the forecasts should be revised. 


\subsection{Now-casting models}

15. For the major OECD and non-OECD economies, the near-term assessment also takes account of projections from a suite of statistical models using high frequency indicators to provide estimates of nearterm quarterly GDP growth, typically for the current and next quarter. These OECD models were first used in the forecasting process after 2000 and build on the work of Sédillot and Pain (2003), Mourougane (2006) and Chalaux and Schwellnus (2014) in using short term economic indicators to predict quarterly movements in GDP by efficiently exploiting monthly and quarterly information. The models combine information from both "soft" indicators, such as business sentiment and consumer surveys, and "hard" indicators, such as industrial production and retail sales, with use being made of different frequencies of data and a variety of estimation techniques. The procedures are relatively automated and can be run whenever major monthly data are released, allowing updating and choice of model according to the information set available.

16. The most important gains from using these models are found to be for current-quarter forecasts made at or immediately after the start of the quarter in question, where estimated indicator models outperform autoregressive time series models, both in terms of size of error and directional accuracy. The main gains from using a monthly approach arise once at least one month of data is available for the quarter being forecast, typically two to three months before the publication of the first official outturn estimate for GDP. For one-quarter-ahead projections, the performance of the estimated indicator models are noticeably better than simpler time series models once one or two months of information become available for the quarter preceding that being forecast. The recent performance of these statistical indicator models, suggest that in 'normal times' without any information for the quarter, the $70 \%$ confidence band around the quarter-on-quarter GDP forecast (non-annualised) averages plus or minus 0.4 percentage points for the major OECD economies, declining to plus or minus 0.3 percentage points when a complete set of monthly indicators is available. ${ }^{5}$

17. Outside of 'normal times', a post-mortem evaluation of forecasts over the period of the financial crisis, concluded the OECD's indicator models for GDP "provided a very useful real-time signal of a significant slowdown and then major contraction" (Pain et al., 2014). The models were slow to predict the strength of the contraction in the third quarter of 2008, but thereafter the downturn and bounce-back were highlighted relatively quickly (Figure 1).

18. A related, but distinct, set of models are the OECD Composite Leading Indicators (CLIs) which are maintained by the OECD Statistics Directorate and which use a wide range of high frequency indicators to provide signals of future turning points in economic activity. Recent analysis suggests that the CLIs were able to anticipate the Great Recession in G7 countries at an early stage, although by their very nature, they could not give an indication about the depth of the coming crisis (Astolfi et al., 2016).

5. The figures quoted are for an average of the United States, Germany, the United Kingdom, France and Italy over the period 2005-14, but excluding the volatile period of the financial crisis 2008-9. They also exclude Japan, for which GDP data is notably more volatile and so the confidence bands correspondingly wider. 
Figure 1. OECD indicator model estimates and G7 GDP growth

Annualised quarter-on-quarter percentage changes, 2007q1 - 2012q4

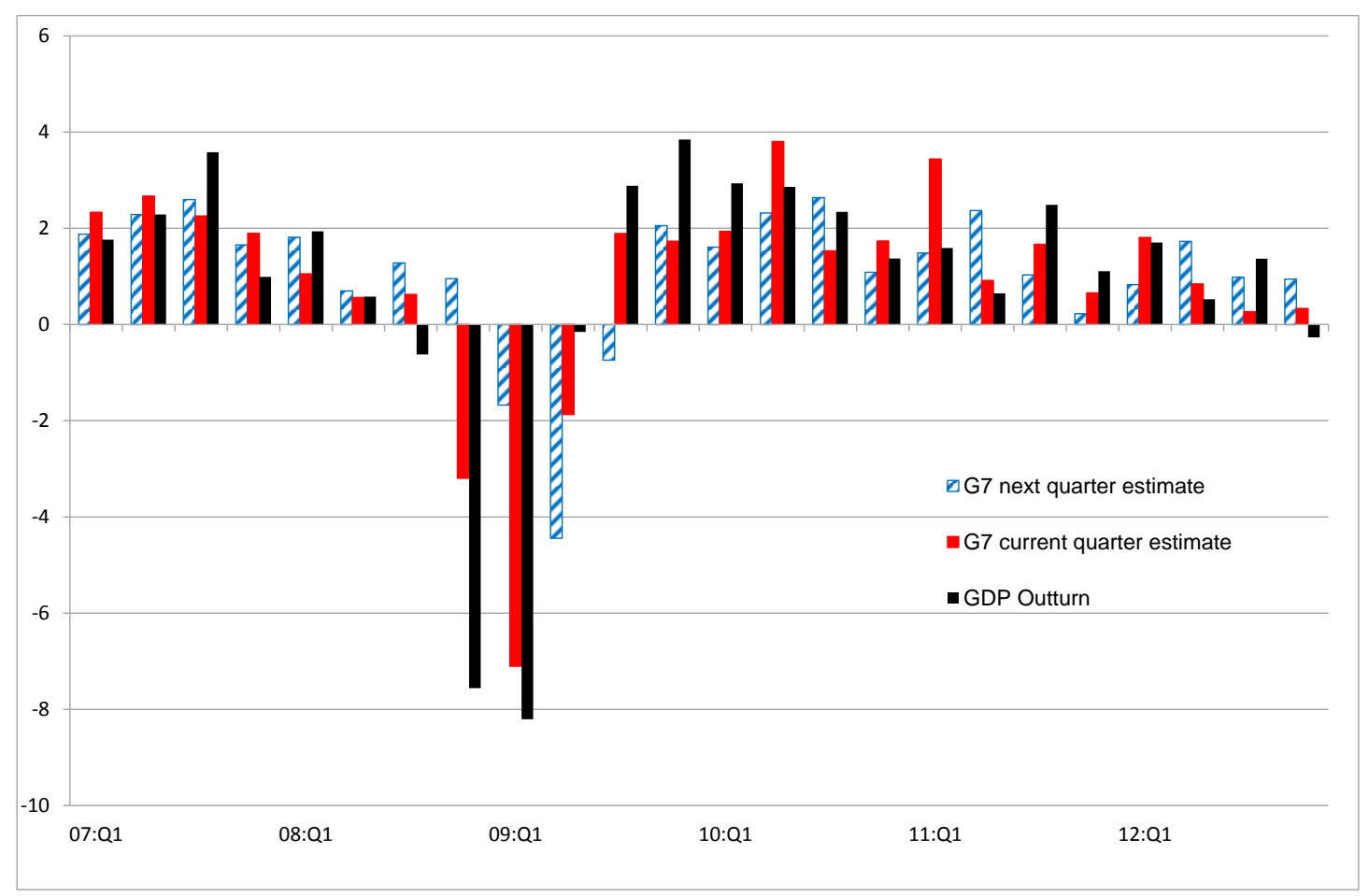

Note: Outturn is defined as the published figure at the following Economic Outlook. Indicator model estimates shown are real-time estimates, typically from the last month of the quarter. Data are weighted using nominal GDP at PPP rates in 2010.

Source: Pain et al. (2004).

\subsection{The Forecast Entry system}

19. The physical input of OECD forecasts is achieved through a purpose-built 'Forecast Entry' system which for the user resembles an elaborate spreadsheet, with different sheets for different subset of variables, such as the labour market, trade or the expenditure components of GDP. The system both centralises the forecast data management process and allows Country Desks to view most recent data outcomes, new information and common assumptions as well as to input and revise the projections for the countries for which they are responsible in a consistent manner. Typically a Country Desk will be responsible for: quarterly forecasts of about 60 macroeconomic variables, with another 150 or so variables being built-up by identities and about 60 variables such as exchange rates or commodity prices being set exogenously according to centrally agreed assumptions. At the same time, the system maintains the consistency and coherence of the data set by incorporating all the relevant national accounts, trade and other accounting identities linking the various concepts. Thus as individual forecast components are updated and submitted, all identities are automatically re-evaluated to provide a fully consistent data set. The system also provides guidelines in the form of equation-based estimates or rules of thumb for more than half of the variables which the Country Desk is responsible for forecasting. Desks are at liberty to use these guidelines, ignore them or replace them with their own equations. The country forecasts are thus ultimately judgementally determined by Desks, subject only to constraints imposed by identities linking the variables and the need to be consistent with exogenously imposed assumptions. 


\subsection{The trade model and global consistency}

20. A small Trade Team is tasked with monitoring the global consistency of trade and the balance of payments throughout the forecast round. While errors and omissions mean that global exports are not equal to global imports in historical data, an objective of the Trade Team is to ensure that these inconsistencies do not grow over the forecast period. A growing global balance-of-payments discrepancy over the forecast horizon would be problematic for the consistency of the forecasts; for example as a matter of accounting, not all countries can simultaneously gain from a boost to net exports. This is of particular relevance when one of the issues which has most exercised policy-makers in recent years is increasing imbalances between countries, as it would imply, so-to-speak, an increasing imbalance of the world with Mars. ${ }^{6}$ Where there are signs of an increasing global inconsistency, the Trade Team endeavours to correct it, usually by interacting with the Desks responsible for the country forecasts which depart from the trade model in a direction which contributes to the global imbalance. The trade model provides projections for the key aggregate national accounts trade variables for each country, which take account of domestic activity, export weighted markets, relative price competitiveness and trend developments (Morin and Schwellnus, 2014).

21. While the OECD's world trade forecast is built as the aggregation of individual country import and export forecasts, additional tools are used to assess the short-term evolution of world trade. Two types of indicator models have been developed to forecast world trade in the short term: one approach uses a bridge equation model based on world industrial production, export orders, technology indicators, oil prices and the Baltic dry index; a second approach is based on a dynamic factor model using an extended dataset of explanatory variables (see Guichard and Rusticelli, 2011). In addition, a global equation linking world trade growth to world GDP growth is used to assess the consistency of world trade and world GDP forecasts, drawing on the work of Ollivaud and Schwellnus (2015). To the extent that possible inconsistencies are identified, this information is used iteratively by the Trade Team in guiding the more detailed forecast components at country and regional levels.

\subsection{Potential output calculations}

22. At the start of each forecast round a small Supply Team produces estimates of potential output for each country over history and the projection period, using a common methodology assuming an aggregate Cobb-Douglas production function (Turner et al., 2016). These initial estimates may then be revised following discussions with the relevant Country Desk, but with the aim of finalising potential output prior to the other macro projections being input. Potential output estimates may then serve as a guide to the forecasts, with GDP usually being projected so that it converges towards potential output and the output gap narrows over the forecast horizon. The output gap may also be taken as an input to inflation projections and the consistency between the output gap and inflation is one element of the forecasts which comes under scrutiny in meetings where the forecasts are reviewed.

23. While potential output is an important concept for policy analysis, it is less clear whether potential output calculations have in practice contributed positively to forecast performance. In particular, the reliability of output gap estimates - in general and not just those made by the OECD - has for a long time been called into question by the large revisions which they are sometimes subjected to (Orphanides and Van Norden, 1999). Revisions to OECD published estimates of the output gap around the period of the financial crisis were exceptionally large, with potential output being consistently over-estimated in the immediate pre-crisis period for all the major OECD countries (Turner et al., 2016).

6. The Economist magazine, in an article titled 'Export to Mars' (The Economist, 2011), highlighted a recent IMF forecast in which the global current account surplus doubled over the forecast horizon, raising the question “Are aliens buying Louis Vuitton handbags?”. 
24. Much of the instability in potential output estimates can be traced back to well-known end-point problems associated with the filtering techniques which usually underpin the calculations. Such end-point problems are likely to be most severe around business cycle turning points. ${ }^{7}$ Recent methodological innovations attempt to better anchor OECD estimates of potential output by incorporating information from other indicators which are correlated with the business cycle (Turner et al., 2016). However, it remains to be seen whether these methodological changes will lead to improved real-time reliability in potential output estimates in future forecasts.

\section{The forecasting track record}

25. The OECD has regularly published reviews of its forecasting performance (Koutsogeorgopoulou, 2000; Vogel, 2007; Pain et al., 2014); this section provides a summary of some of the key findings from these reviews.

\subsection{Forecast performance for the current year is much better than for the following year}

26. It is not surprising that forecast errors tend to increase with the length of the forecast horizon, but current year forecasts also display a number of desirable properties which are not present in one-yearahead forecasts. ${ }^{8}$ Vogel (2007) analyses GDP growth forecasts for the G7 over the pre-crisis period 19912006 and finds:

- Current-year projections are unbiased, whereas one-year-ahead projections tend to persistently overestimate outcomes during low-growth episodes and show little sensitivity to initial cyclical conditions;

- Current-year projections add value to naïve forecasts, such as the sample means or previous realisations, but this is not the case for one-year-ahead forecasts, for which on average naïve forecasts were found to be a more accurate guide;

- Current-year forecasts correctly predict turning points in about three-quarters of cases, but only $6 \%$ of cases in one-year-ahead forecasts.

27. Pain et al. (2004) analyse GDP growth forecasts over the period 2007-12, including the crisis, and find:

- Formal tests of bias, suggest that both current-year and one-year-ahead forecasts tended to be systematically over estimated over the period 2007-12, but the average over prediction for OECD countries for the current year was only 0.15 percentage points, whereas for the one-year-ahead forecast it was 1.5 percentage points, i.e. ten times greater;

- Formal statistical tests suggest that both current-year and one-year ahead forecasts do not 'encompass' a naïve forecast, although the magnitude of the estimated coefficients are such as to

7. One common approach to dealing with such end-point problems is to add forecasts to the end of the historical data before filtering. While this may ensure some internal consistency between the forecasts and potential output projections, it is then difficult to argue that the potential output calculations also represent an independent input to GDP forecasts.

8. For the purposes of this paper, current-year forecasts refer to those published in May of the same year, whereas one-year-ahead forecasts refer to the May forecast for the following year. 
suggest that, for practical purposes, current-year forecasts come close to encompassing a naïve forecast. ${ }^{9}$

- Analysing the directional accuracy of G7 growth forecasts over a longer period (1971-2012), current-year forecasts are found to correctly predict growth accelerations and decelerations in 80$90 \%$ of cases, but one-year-ahead forecasts correctly identify growth decelerations in less than $50 \%$ of cases.

\subsection{Current-year forecast performance has improved over time}

28. Abstracting from the immediate impact years of the financial crisis, current-year forecasts of GDP growth have tended to improve over time. Thus the root mean square forecast error of GDP growth for the G7 countries for the current year has tended to fall both in absolute terms (Figure 2) and when normalised on the volatility of GDP growth (Table 2). ${ }^{10}$ The decline in the RMSE probably partly reflects a decline in the volatility of GDP growth, however the RMSE has continued to decline even though the volatility of growth has picked up after the crisis. On the other hand, there is no obvious sign of any trend improvement in the corresponding one-year-ahead forecasts. One limitation to future improvements in forecast accuracy is the tendency for outturn GDP data to be revised; there is a strong positive correlation across G7 countries between the size of root-mean-square revision (RMSR) of GDP and the current year forecast of GDP over the decade to 2011. ${ }^{11}$ Nevertheless, there should still be scope to improve forecast performance as on average across the G7, the RMSR of GDP is about half the current-year-forecast RMSE, a difference of about 0.3-0.4 points of GDP.

Table 2. The root-mean-square error of OECD GDP growth forecasts

Unweighted mean of G7 countries

\begin{tabular}{lcccc}
\hline & \multicolumn{2}{c}{ Percentage points of GDP } & \multicolumn{2}{c}{ Ratio to standard deviation of growth } \\
\cline { 2 - 5 } & $\begin{array}{c}\text { May projection for } \\
\text { current year }\end{array}$ & $\begin{array}{c}\text { May projection for } \\
\text { next year }\end{array}$ & $\begin{array}{c}\text { May projection for } \\
\text { current year }\end{array}$ & $\begin{array}{c}\text { May projection for } \\
\text { next year }\end{array}$ \\
\hline $1971-2012$ & 1.0 & n.a. & 0.4 & n.a. \\
\hline $1971-1981$ & 1.3 & n.a. & 0.5 & n.a. \\
$1982-1990$ & 1.0 & 1.7 & 0.6 & 1.0 \\
$1991-2006$ & 0.7 & 1.6 & 0.5 & 1.2 \\
$2007-2012$ & 0.7 & 2.7 & 0.3 & 1.1 \\
\hline
\end{tabular}

Note: Errors are calculated as actual growth less projected growth at each forecast horizon, where actual growth is the published outturn as at May the following year. May projections for the following year are only available from 1982.

Source: Pain et al. (2014).

9. The formal test involves regressing the outcome on an intercept, lagged outcome and official forecast with the official forecast 'encompassing' a naïve forecast if the regression coefficients on the intercept and lagged outcome are insignificantly different from zero. While the current-year coefficient on the lagged outcome is statistically significant, its value is only -0.07 whereas the coefficient on the forecast $(0.95)$ is close to unity and the intercept term is insignificant.

10. For more detailed results of individual G7 countries see Appendix 1 of Pain et al. (2014). Table 4 in Pain et al. (2014) extends Table 2 in the current paper by including results for the November projection for next year; in all cases the November projection error is roughly half way between the error of the May projection for the current year and the May projection for the next year.

11. The revision to outturn GDP data is measured here as the revision for year $\mathrm{t}$ between the May Economic Outlook of year $(\mathrm{t}+1)$ and the May Economic Outlook of year $(\mathrm{t}+2)$. 
Figure 2. Forecast accuracy and volatility of GDP growth

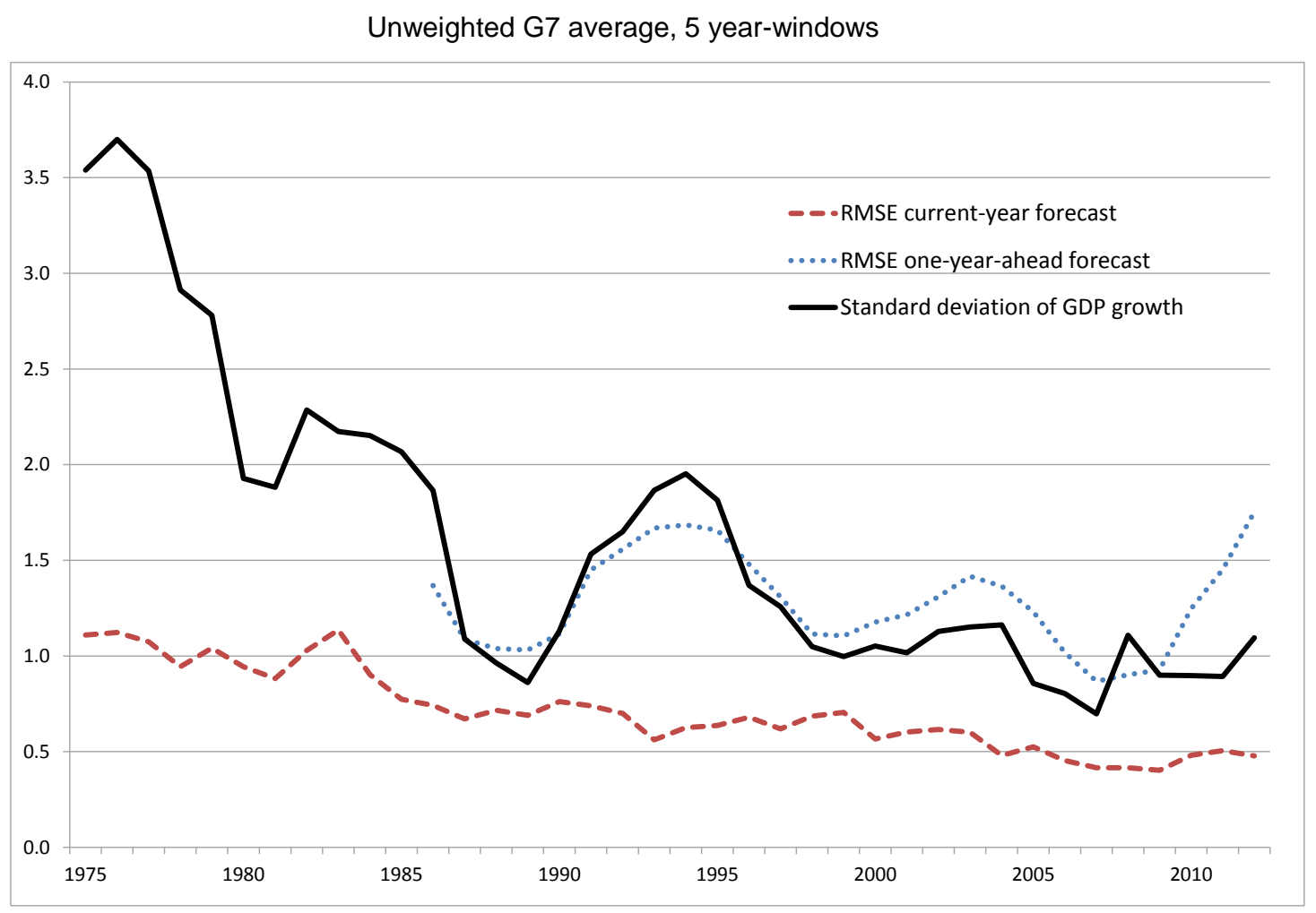

Note: Data points are for five-year averages of rolling windows, but exclude the immediate impact of the financial crisis by excluding 2008 from the calculation of the RMSE of the current-year forecast and by excluding 2009 from the calculation of the one-year-ahead forecast and the standard deviation of growth.

Source: Adapted from data in Pain et al (2014).

\subsection{Forecasts are strikingly similar to the consensus and other international organisations}

29. There is a close correlation in forecast errors between the forecasts published by the OECD, IMF, NIESR and Consensus forecasts. This synchronicity of errors is most striking for the one-year-ahead forecasts (Figure 3), especially given the paucity of these forecasts in other respects, as discussed previously in section 4.1. For the major seven economies, over the period 1991-2011, the average absolute difference in one-year-ahead forecasts between the OECD and IMF, or OECD and consensus, is $0.3-0.4$ percentage points, which is typically about one-quarter of the size of the average absolute error across all forecasts for the respective country, with the latter varying from 1.1 percentage points for France to 2.1 percentage points for Japan (Figure 3). ${ }^{12}$ Over the entire period 1991-2011 and for all G7 countries, the difference between all possible forecast pairs has exceeded the average absolute forecast error for that country in only $1 / 2$ per cent of all cases (with these all occurring around the financial crisis). ${ }^{13}$

12. Comparisons of OECD forecasts with those of the European Commission, as well as the IMF and consensus, over the period 2007-12 find similar synchronicity of errors, see in particular Figure 11 of Pain et al. (2014).

13. Given four forecasters of seven countries over a period of 21 years, there are 882 possible pairwise comparisons. In only five of these pairwise comparisons does the difference between a pair of forecasters 


\subsection{Forecasts are still particularly vulnerable around major global shocks}

30. Forecast errors of the OECD and other international organisations were unusually large around the financial crisis with the largest errors occurring at the height of the financial crisis; the average unweighted error (over-prediction) across all OECD countries of GDP growth forecasts made in May 2008 for calendar year 2009 was more than 5 percentage points (see Figure 11 of Pain et al., 2014).

31. Such forecast failings are, however, not unprecedented, with forecast errors being of a similar order of magnitude to those experienced around the first oil price shock in the early 1970s. The experience of the 1970s was seen as a learning opportunity by modellers; for example, Klein (1982) argued that "the principal issue is that models did not properly integrate food, fuel and flexible exchange rates into their equation systems". Similarly, a review of the forecasting failures around the financial crisis has led to changes in forecasting models and procedures (Pain et al., 2014), some of which are referred to elsewhere in this paper, which hopefully will improve forecasting performance. Nevertheless, their poor performance over the period of the financial crisis serves as a reminder of the limitation of macroeconomic forecasts in the face of major global shocks. It also reinforces the case for scenario analysis to examine the implications of costly tail risks, especially because their precise timing is usually hard to predict.

exceed the average forecast error for that country over the whole sample period. These occurrences are for the United States, United Kingdom and Germany in either 2009 or 2010. 
Figure 3. One-year-ahead forecast errors for GDP growth

Percentage points
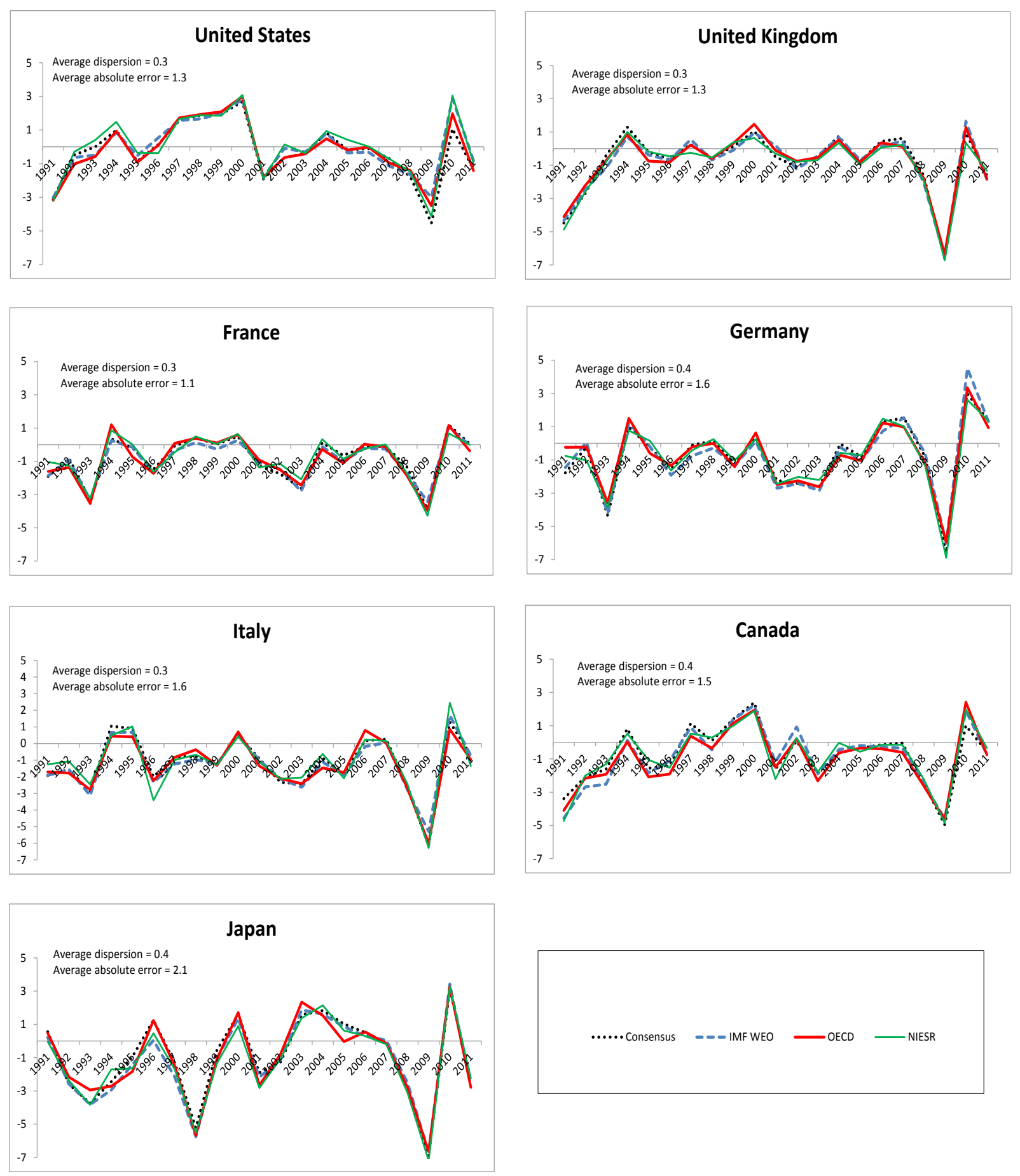

Note: One-year-ahead forecast errors are calculated from the May forecast of the preceding year. The outturn for GDP growth is taken as the realisation two years later (to allow for data revisions). The 'average dispersion' is the average difference in forecast errors (and, by implication, also forecasts) across all pairwise forecasts. The 'average absolute error' is the average error across all forecasts.

Source: Independent Evaluation Committee of the IMF (2014) and Pain et al. (2014). 
ECO/WKP(2016)60

\section{Concluding remarks}

32. Any macroeconomic forecast is likely to be partly model-based and partly judgement-based. The forecasting process at the OECD is designed to give a high weight to expert judgement, subject to close and repeated scrutiny. The approach is similar to that adopted in other international organisations such as the IMF and European Commission [Independent Evaluation Office of the IMF (2014); ADE and DIW (2007)]. The advantage of this approach is that it places much of the responsibility for forecasting on country experts who follow day-to-day economic developments in that country and allows them to adopt whatever model (formal or otherwise) that they judge best suited to capture the particular features of the economy in question. While OECD forecasts cannot be traced back to a single global model, a variety of models do play a role in the forecast process as described in Section 3.

33. What would be the potential benefits and costs of generating OECD forecasts directly from a single global model? An advantage of model-based forecasts is that it is possible to identify the contribution to forecast errors from model errors, incorrect judgements about exogenous factors or errors of judgement by forecasters (see Wallis et al., 1984, 1985, 1986 and 1987). Such feedback might possibly lead to future improvements in forecasting performance, including in model specification. A more modelbased forecast might also enhance consistency with a narrative on the global economy and scenario analysis, particularly if some important developments are likely to play out beyond the short-term forecast horizon. On the other hand, greater reliance on a global model would risk leading to a loss of accountability and ownership by the country experts who deal on a bilateral basis with national governments. This would be particularly unfortunate to the extent that the macroeconomic outlook provides an important context for policy analysis and recommendations in OECD country surveys. The remaining remarks speculate on how the particular combination of models and judgement involved in OECD forecasts may have influenced the forecasting track record.

34. The performance of OECD forecasts as summarised in section 4, is mixed; the track record for current-year forecasts appears more positive, being unbiased, encompassing naïve forecasts and mostly identifying turning points. There are also some signs of a trend improvement with a gradual decline in the root-mean-square error of current-year forecasts. Conversely, one-year-ahead forecasts are often little better than naïve forecasts and display no obvious signs of trend improvement. Perhaps of greater concern -- given that the forecasts are the basis for policy assessment and advice -- is that one-year-ahead forecasts are biased and particularly poor at anticipating downturns. This record is consistent with more recent analyses of both statistical models and professional forecasters which suggest that forecast performance of GDP growth is poor beyond horizons further ahead than one quarter [Stark (2000); Jansen et al. (2016)]. It is possible that future improvements in forecast performance may come about through better modelling of underlying relationships between macroeconomic variables. For example, recent OECD research has analysed the relationships between key macroeconomic variables given a suspicion that the transmission mechanism between such variables may have changed. ${ }^{14}$ On the other hand, poor forecast performance at longer horizons may just reflect the complex, dynamic and non-linear nature of the processes underlying economic growth, so that unforeseen future events or small differences in initial conditions can have large unforeseen consequences (Kay, 2003).

35. The trend improvement in current-year forecasting performance is probably partly explained by a decline in the volatility of GDP growth and possibly the increased accessibility and timeliness of national accounts data and other hard indicators. However, more recent improvements in current-year forecast performance, despite increased volatility of post-crisis growth, are likely due to the introduction of,

14. Such research includes analysis of the relationship between: investment and interest rates (OECD, 2015a); the exchange rate and trade (Ollivaud et. al., 2015); and the labour market and inflation (Rusticelli et al., 2015). 
increasing weight given to, and improved performance of, high frequency now-casting indicator models to forecast the current and next quarter GDP. For the May current-year GDP forecast, an outturn for the first quarter will sometimes be available, with the indicator models providing guidance for the second and third quarter growth rates, while the fourth quarter growth rate has relatively little weight in the calculation of the calendar year-on-year growth rate (Cross and Wyman, 2012). In these circumstances, accurate predictions from the indicator models virtually guarantee a reasonable forecast of year-over-year GDP growth for the current calendar year (notwithstanding subsequent data revisions). Research at the OECD is ongoing to further improve these models,${ }^{15}$ and future developments, including the possibility of making use of 'big data', suggest further improvements in short-term forecasting performance might be possible.

36. As well as the poor performance of one-year-ahead forecasts, it is disconcerting that errors are so similar across international organisations and consensus forecasts, not just on average, but on a period-byperiod basis (as illustrated in Figure 3). ${ }^{16}$ To some degree this is the inevitable consequence of all forecasters failing to anticipate major future economic events, such as oil shocks or financial crises coupled with forecasters' tendency to predict a relatively rapid reversion to long-run trend growth rates. This may be reinforced by herding behaviour among forecasters as "it is always safer to be wrong in a crowd" (Kay, 1995). Such herding behaviour is discussed in a recent review of IMF forecasts: "desk economists may hesitate to deviate from consensus forecasts, because "rocking the boat" in this way would call for lengthy and elaborate justifications in the course of the departmental and interdepartmental review process" (Independent Evaluation Office [IEO] of the IMF, 2014). An interesting question is whether dispersion is likely to be greater among forecasts which are more model-based than judgement-based. An example of the greater dispersion of more model-based forecasts are the published forecasts of UK GDP growth over the 1980s generated on rival models analysed in detail by the ESRC Macroeconomic Modelling Bureau. ${ }^{17}$ On the other hand, forecasts for the G7 countries of one-year-ahead GDP growth published by the National Institute for Economic and Social Research and generated on the NiGEM model exhibit a similar synchronicity of forecast errors with consensus, IMF and OECD forecasts (Figure 3). ${ }^{18}$ This may be because macroeconomic models typically have an intrinsic property towards mean reversion (Kay, 1995), which may also characterise more judgementally-based forecasts which assume a reversion to historical

15. Recent OECD research (Ollivaud et al., 2016) has compared the forecasting performance of 'state-of theart' Dynamic Factor Models that synthesize information from a large number of indicators against smallscale bridge models which are currently used at the OECD. It concludes that monitoring a large number of indicators adds noise rather than relevant information and so there is no gain from switching from the models currently being used.

16. While there is also a high degree of synchronicity among current-year forecasts it is less disconcerting. Firstly, this is because current-year forecasts exhibit many desirable properties (unbiasedness, identification of turning points and bettering of naïve forecasts) which year-ahead forecasts do not. Secondly, relative to average forecasts errors the dispersion in current-year forecasts is greater than that of year-ahead forecasts.

17. See for example Figure 1 in Wallis (1989) and Table 4.7 of Wallis et al. (1987). These forecasts are more model-based in the sense that the forecasts can be explicitly linked to a single model, with judgement being applied in the setting of the pattern of equation residual adjustments (the difference between the actual outcome or forecast and that predicted by the model equation) over the forecast horizon. In many practical forecasting exercises such residuals are not set to zero over the forecast horizon, but may be extended as some average of their recent historical past, or extrapolated by applying some rate of decay or follow some other pattern based on the forecaster's judgement of what was causing the historical errors in the first place (Turner, 1990). This also means that the difference between model-based and judgement-based forecasts is often blurred.

18. See Kirby et al. (2015) for an evaluation of NIESR's forecast performance for the United Kingdom, United States and euro area. 
growth trends following any initial deviation. A corollary is that it would be surprising if greater reliance on a global model to generate OECD forecasts led to a significant improvement in forecast performance.

37. After reviewing the experience of forecasting over the crisis period, most international organisations have made a greater effort to characterise the risk distribution around their baseline forecast (Pain et al., 2014). In the case of the OECD, this has been through giving greater emphasis to commentary as to whether risks are balanced around the central forecast and through the increased use of model-based scenario analysis to illustrate key risks. Other international organisations, such as the IMF, have gone further in publishing forecast ranges, fan charts and assessments of the likelihood of the occurrence of particular events, such as recession or deflation. The OECD has also recently been carrying out work to evaluate the usefulness of early warning indicators which can signal the probability of an imminent severe recession or crisis [Hermansen and Röhn (2015); Röhn et al. (2015)], although this has not yet been incorporated as part of the regular commentary around the central forecast. Such developments, which explicitly recognise the inevitable uncertainty around global macroeconomic forecasts, appear particularly appropriate given the paucity of the forecast track-record beyond the current year, especially in predicting downturns. Such developments also represent another way in which different models, broadly defined, can have an important influence on global macroeconomic forecasts and their presentation. 


\section{REFERENCES}

Astolfi, R., et al. (2016), "The use of short-term indicators and survey data for predicting turning points in economic activity: A performance analysis of the OECD system of CLIs during the Great Recession", OECD Statistics Working Papers, No. 2016/08, OECD Publishing, Paris. DOI: http://dx.doi.org/10.1787/5jlz4gs2pkhf-en

Baker, J. et al. (2016), "Technical Appendix: NiGEM Overview", Appendix B to "Modelling events: The short-term economic impact of leaving the EU", Economic Modelling, Vol. 58, DOI:https://doi.org/10.1016/j.econmod.2016.06.012.

Chalaux, T. and C. Schwellnus (2014), "Short-term indicator models for quarterly GDP growth in the BRIICS: a small-scale bridge model approach", OECD Economics Department Working Papers, No. 1109, OECD Publishing, Paris, DOI: http://dx.doi.org/10.1787/5jz5t6b77rg4-en.

Cross, P. and D. Wyman (2012), "The Relationship between Monthly, Quarterly and Annual Growth Rates", Canadian Economic Observer, December, http://www.statcan.gc.ca/pub/11-010x/2011006/part-partie3-eng.htm.

Dalsgaard, T., C. André and P. Richardson (2001), "Standard shocks in the OECD interlink model", OECD Economics Department Working Papers, No. 306, OECD Publishing, Paris, DOI: http://dx.doi.org/10.1787/000706200171.

The Economist (2011), "Exports to Mars", http://www.economist.com/node/21538100?fsrc=scn/tw/te/ar/exportstomars, 12 November.

Guichard, S., D. Haugh and D. Turner (2009), "Quantifying the effect of financial conditions in the euro area, Japan, United Kingdom and United States", OECD Economics Department Working Papers, No. 677, OECD Publishing, Paris, DOI: http://dx.doi.org/10.1787/226365806132.

Hermansen, M. and O. Röhn (2015), "Economic resilience: The usefulness of early warning indicators in OECD countries", OECD Economics Department Working Papers, No. 1250, OECD Publishing, Paris, DOI: http://dx.doi.org/10.1787/5jrxhgfqx3mv-en.

Hervé, K., et al. (2010), “The OECD's new global model”, OECD Economics Department Working Papers, No. 768, OECD Publishing, Paris, DOI: http://dx.doi.org/10.1787/5kmftp85kr8p-en.

IEO (2014), "IMF Forecasts: Process, Quality, and Country Perspectives", Independent Evaluation (IEO) of the International Fund, http://www.ieo-imf.org/ieo/pages/EvaluationImages181.aspx.

IMF (2013), “The dog that didn't bark: has inflation been muzzled or was it just sleeping”, chapter 3, World Economic Outlook, April.

Jansen, W. J., X. Jin and J. M. de Winter (2016), "Forecasting and nowcasting real GDP: Comparing statistical models and subjective forecasts", International Journal of Forecasting, 32 (2), pp. 411436.

Kay, J. (1995), “The Failures of Economic Forecasting”, 25 September, http://www.johnkay.com/1995/09/25/the-failures-of-economic-forecasting. 
Kay, J. (2003), "Economic Forecasting will never be an exact science", Financial Times, 23 October, http://www.johnkay.com/2003/10/29/economic-forecasting-will-never-be-an-exact-science.

Kirby S., K. Paramaguru and and J. Warren (2015), "The Accuracy of NIESR's GDP Growth Forecasts", National Institute Economic Review, No. 232, May.

Klein, L. (1982), Econometric Models as Guides for Decision Making, ISBN 0-02-917430-9.

Koutsogeorgopoulou, V. (2000), “A post-mortem on Economic Outlook projections", OECD Economics Department Working Papers, No. 274, OECD Publishing, Paris

DOI: http://dx.doi.org/10.1787/351822846618.

Morin, M. and C. Schwellnus (2014), "An update of the OECD international trade equations", $O E C D$ Economics Department Working Papers, No. 1129, OECD Publishing, Paris, http://dx.doi.org/10.1787/5jz2bxbkrxmv-en.

OECD (2016), OECD Economic Outlook, No. 99, May, OECD Publishing, Paris, http://www.oecd.org/eco/outlook/economic-outlook/

OECD (2015), OECD Economic Outlook, No. 98, November, OECD Publishing, Paris.

OECD (2014a), OECD Economic Outlook, No. 95, May, OECD Publishing, Paris.

OECD (2014b), OECD Economic Outlook, No. 96, November, OECD Publishing, Paris.

OECD (2013), OECD Economic Outlook, No. 93, May. OECD Publishing, Paris.

OECD (2012), OECD Economic Outlook, No. 92, November, OECD Publishing, Paris.

Ollivaud, P., et al. (2016), "Short-term forecasting GDP: A contest between small-scale bridge and largescale dynamic factor model", OECD Economics Department Working Papers, No. 1313, OECD Publishing, Paris. DOI: http://dx.doi.org/10.1787/5jlv2jj4mw40-en

Ollivaud, P., and C. Schwellnus (2015), "Does the post-crisis weakness of global trade solely reflect weak demand?", OECD Economics Department Working Papers, No. 1216, OECD Publishing, Paris, http://dx.doi.org/10.1787/5js1qunff3hk-en.

Ollivaud, P., E. Rusticelli and C. Schwellnus (2015), "The changing role of the exchange rate for Macroeconomic Adjustment", OECD Economics Department Working Papers, No. 1190, OECD

Publishing, Paris.

DOI: http://dx.doi.org/10.1787/5js4rfhjf15l-en

Pain, N., et al. (2014), "OECD forecasts during and after the financial crisis: a post mortem", OECD Economics Department Working Papers, No. 1107, OECD Publishing, Paris, DOI: http://dx.doi.org/10.1787/5jz7311qw1s1-en

Rae, D. and D. Turner (2001), "A Small Global Forecasting Model", OECD Economics Department Working Papers, No. 286, OECD Publishing, Paris, DOI: http://dx.doi.org/10.1787/628640803664.

Richardson , P. (1988), "The Structure and simulation properties of the OECD's INTERLINK model", OECD Economic Studies, No. 10, Spring, OECD Publishing, Paris, http://www.oecd.org/eco/outlook/31705400.pdf. 
Röhn,O., et al. (2015), "Economic resilience: A new set of vulnerability indicators for OECD countries", OECD Economics Department Working Papers, No. 1249, OECD Publishing, Paris, DOI: http://dx.doi.org/10.1787/5jrxhgjw54r8-en.

Rusticelli, E., D. Turner and M. Cavalleri (2015), "Incorporating Anchored Inflation Expectations in the Phillips Curve and in the Derivation of OECD Measures of Equilibrium Unemployment", OECD Economics Department Working Papers, No. 1231, OECD Publishing, Paris. DOI: http://dx.doi.org/10.1787/5js1gmq551wd-en.

Sedillot, F. and N. Pain (2003), Indicator models of real GDP growth in selected OECD countries, OECD Economics Department Working Papers, No. 364, OECD Publishing, Paris, http://EconPapers.repec.org/RePEc:oec:ecoaaa:364-en.

Stark, T. (2010), "Realistic evaluation of real-time forecasts in the survey of professional forecasters", Research Rap Special Report, https://ideas.repec.org/a/fip/fedprr/y2010imayx1.html.

Turner, D. S. (1990), "The role of judgement in macroeconomic forecasting", Journal of Forecasting, 9, pp. 315-345.

Turner, D., et al. (2016), "An investigation into improving the real-time reliability of OECD output gap estimates", OECD Economics Department Working Papers, No. 1294, OECD Publishing, Paris. DOI: http://dx.doi.org/10.1787/5jm0qwpqmz34-en

Vogel, L. (2007), "How do the OECD growth projections for the G7 economies perform?: A postmortem", OECD Economics Department Working Papers, No. 573, OECD Publishing, Paris. DOI: http://dx.doi.org/10.1787/111804483765.

Wallis, K. F. (1989), “Macroeconomic Forecasting: A Survey”, The Economic Journal, March, pp. 28-61.

Wallis, K. F. (ed.) (1987), “Models of the Economy”, Oxford University Press, Oxford.

Wallis, K. F. (ed.) (1986), “Models of the Economy”, Oxford University Press, Oxford.

Wallis, K. F. (ed.) (1985), “Models of the Economy”, Oxford University Press, Oxford.

Wallis, K. F. (ed.) (1984), “Models of the Economy”, Oxford University Press, Oxford. 